\title{
Playing On: John York and the Sydney Brass Musical Instrument Factory
}

\author{
ANDREW EVANS
}

$\mathrm{T}$

The history of John York and the Sydney Brass Musical Instrument Factory contains familiar elements of a quintessential nineteenthcentury Australian narrative. It features a skilled English immigrant who brought his family to a developing capital city and became a manufacturer and small business owner. It is an unusual story in that York practised the specialised skill of brass instrument making and repairing and was one of a handful of brass instrument makers known to have operated in Sydney at the time. ${ }^{1}$

At the end of the nineteenth century the significant purchasing power of an expanding Australian middle class, and a strong demand for the many musical instruments required for home entertainment, generated vigorous competition amongst Sydney's music retailers. Cheaper British mass produced instruments were aggressively marketed 
by Palings and Nicholsons whose 'emporiums' were located at the more fashionable northern end of George Street. In order to succeed in this market, John York's reputation as an instrument maker and repairer was paramount. This was largely founded on the promise of consistent, high quality workmanship and superior, personalised service. Even after his death in 1910, this enduring reputation sustained loyalty from York's customers well into the middle of the twentieth century when the business continued under the management of his wife and sons.

This exploration of the fluctuating fortunes of York's business reveals his involvement with local Sydney brass band communities and also identifies and assesses the impact of cheaper, imported instruments on the viability of his business. It also explores some surviving documentation that illustrates his methods of manufacture, marketing and advertising, providing a rare view of early twentieth-century, small scale manufacturing in Sydney.

A disappointing aspect of this story of John York's 'Sydney Brass Musical Instrument Factory' is that, to date, no brass instruments made by York appear to have survived. Although the search continues, especially within the few remaining regional band communities, the lack of such an artefact is worrying and the chances of finding one are poor. This disappearance of Australia's early musical heritage, largely through indifference and ignorance is a great loss. Other possible reasons for the absence of York's instruments from our cultural collections will also be discussed.

\section{JOHN YORK SENIOR ARRIVES IN SYDNEY}

After serving an apprenticeship in a renowned Manchester instrument factory, John York senior reached Sydney in 1884 alone. $^{2}$ The announcement of his imminent arrival emphasised his specialization:

MUSICAL INSTRUMENT MAKER (Brass), - The

Advertiser, who will arrive in Sydney per the s.s. Duke of Sutherland, due about the $15^{\text {th }}$ January, will be glad to place his services at the disposal of anyone requiring such in the above trade. Letters to be addressed to John York, general Post Office, till called for. ${ }^{3}$

Born in 1834 in Tipton near Birmingham, little is known of the life of John York senior before coming to Australia. His father had been a hinge-maker and John York had married at the age of twenty and was the father of at least four children. ${ }^{4}$ Tipton was located in what was known as the Black Country due to the rich seams of coal and iron ore 
that ran just beneath the surface. During the nineteenth century these mineral resources provided power and raw materials to the thousands of ironworking foundries and forges operating in the area, making the West Midlands then one of the most industrialised and polluted areas in the world. The majority of men were employed in mining or the metal trades and it is likely John York senior worked in a forge or mine. ${ }^{5}$ It is also likely that he came into contact with one of the many brass bands operating in the area, initiating an interest in the manufacture and repair of brass instruments.

\section{THE RISE OF THE BRASS BANDS IN INDUSTRIALISED BRITAIN}

There was a proliferation of brass bands in this heavily industrialised area that began in the 1840s. Trevor Herbert neatly summarizes some possible reasons for this phenomenon:

The availability of relatively cheap instruments that were comparatively easy to play... the new social environment in which working people found themselves, and the commonly held belief among the most influential in society that music was a path to rectitude, combined to provide the context which nurtured the mid-century development of brass banding. ${ }^{6}$

Most employers encouraged and supported the formation of these ensembles, although not necessarily because they wished to be viewed as generous patrons of the 'arts'. It has been proposed that employee participation in brass bands surreptitiously provided mine owners and operators with a considerable amount of control over the rather limited leisure time of their employees. ${ }^{7}$ Participation in a brass band did require a considerable commitment from players in order to attend rehearsals and concert engagements and to engage in private practice. With supposedly little remaining time to indulge in 'less desirable' habits such as drinking and gambling, a workforce occupied by 'banding' was theoretically more stable and reliable, thus increasing owners' profits from a relatively small investment. Given that today such forms of community music making, such as choirs and concert bands, reinforce social bonds and community cohesion, boost self-esteem and occupy leisure time in a 'constructive' manner, the attitudes of these employers should not be viewed as a particularly isolated or unique social experiment involving the working classes of nineteenth-century Britain. 


\section{BRASS BANDS IN AUSTRALIA}

The first bands in Australia consisted of 'fifes and drums'. These early ensembles were made up of marines and they participated in military parades and processions, providing music for vice-regal occasions and official functions. Beginning with the arrival of large numbers of British and European miners during the 1840s, the more familiar form of the brass band began to spread throughout Australia. Some of the oldest bands in Australia founded by these immigrant miners continue to rehearse and perform over 170 years later. ${ }^{8}$

The development and expansion of the brass band movement was paralleled in the mining towns and manufacturing areas of Australia but on a much smaller scale than seen in the industrial centres of Britain. It was often through involvement in the brass band movement that the immigrant miners found companionship or 'mateship' within these ensembles and they would have also derived pleasure in preserving traditional cultural ties with their homelands. The working conditions in Australian mines and factories were often dangerous and dirty, sometimes in extremely isolated settlements. The chance to make music together on a regular basis and to entertain the rest of the community at fetes and picnics would have enhanced life. Social bonds were strengthened and it would be through these strong networks that the Yorks developed a dependable customer base on which to build their business.

\section{AN APPRENTICE IN THE HIGHAM FACTORY, MANCHESTER}

It has been suggested that John York senior had some involvement with the brass band movement when he decided to apprentice his third son, John York junior (1859-1910), to the prestigious Higham Band Instrument Factory at the age of fourteen. Joseph Higham opened his factory in Manchester in 1842. At its peak the factory was producing over 1000 instruments a year. ${ }^{9}$ These instruments were exported all over the world - Australia included - and the firm had lucrative government contracts with the British Army and Navy. ${ }^{10}$ Surviving photographs of the interior of the factory illustrate the large-scale manufacturing processes and the significant number of employees involved with the production of such volumes of brass instruments. ${ }^{11}$ 


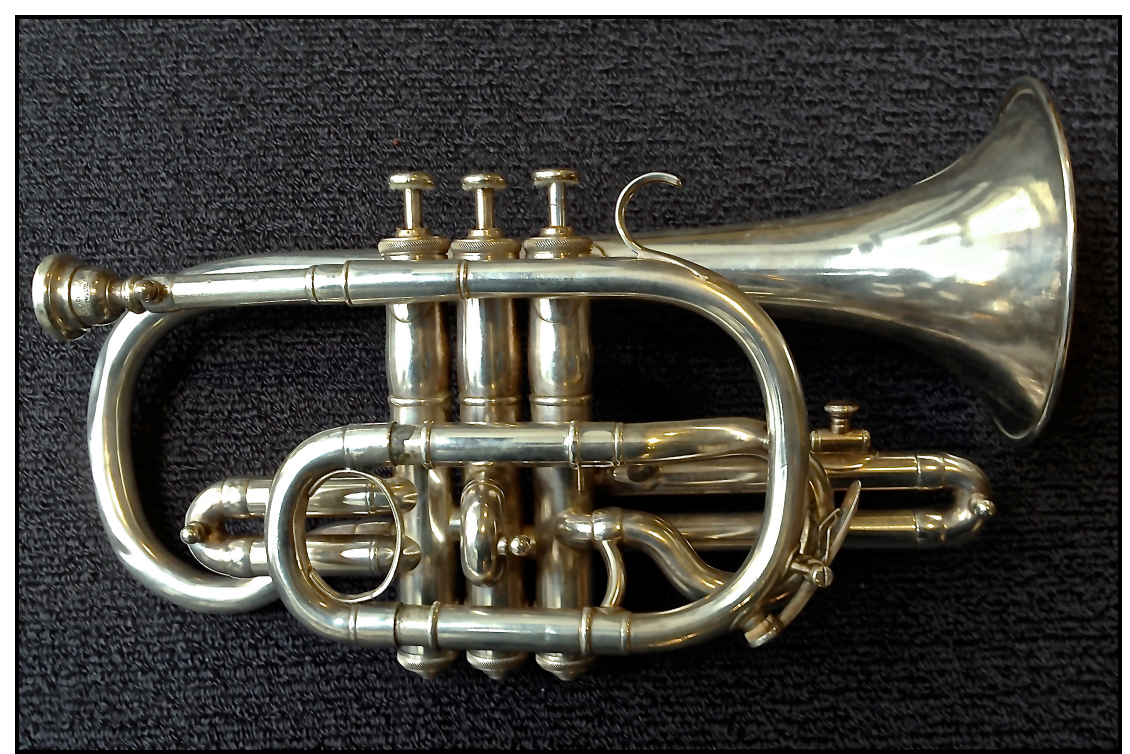

Fig 1 Bb Cornet c1880 by Joseph Higham, Manchester, England (from the author's collection)

A high level of precision engineering was needed for the manufacture of such musical instruments. Most individual instrument makers (including Higham) had numerous patents for various types of valves and pistons, ${ }^{12}$ and their manufacture of which required precise measurements and tooling - thus most of these men were highly skilled craftsmen. The influence of Higham upon John York's Sydney business was to be profound, not only in the reputedly fine technical skills he had gained during his apprenticeship, ${ }^{13}$ but also in many aspects of the marketing of its brass instruments, which will be examined shortly.

\section{The EXTended YoRK Family in ChIPPEndale}

John York senior's reasons for emigrating are unknown but it possible that he realized that as a brass instrument maker and repairer his specialized skills could offer new possibilities for employment. It is also likely that he encouraged his sons, John York junior, aged twenty-six, and Thomas, eighteen, to join him. John junior's wife Elizabeth and their three small children arrived in Sydney in August 1885. ${ }^{14}$

By 1886, all of the Yorks were residing in Elim Place, Chippendale, near the present corner of Broadway and City Road, where the few remaining sandstone workers' cottages are now heritage-listed. ${ }^{15}$ Chippendale was a suburb of workers' cottages dotted amongst factories, mills and distilleries. Unsuitable development during the nineteenth century did little to improve the living conditions of most 
of its inhabitants. Flooding was a regular feature of the area as it was built around a number of watercourses and pollution from the nearby industries must have made the lives of many residents squalid and unhealthy. However, this densely inhabited suburb was to become the focus of the life and business of the York family. Their first accommodation - at 1 Elim Place - was most likely far from salubrious. It is possible that the cottage would have already been at least 50 years old. ${ }^{16}$ It is unknown how long the York family stayed here but it appears that John York junior immediately set to work as a brass instrument maker and repairer in competition with his father and younger brother, Tom. ${ }^{17}$

The York family expanded rapidly. John and Elizabeth were to have eleven children born after their arrival in Sydney, only three of which survived childhood. ${ }^{18}$ By 1891 , the Yorks were renting a cottage at 47 Regent Street, Chippendale. ${ }^{19}$ They moved to a number of addresses in this particular street during the next decade. ${ }^{20}$

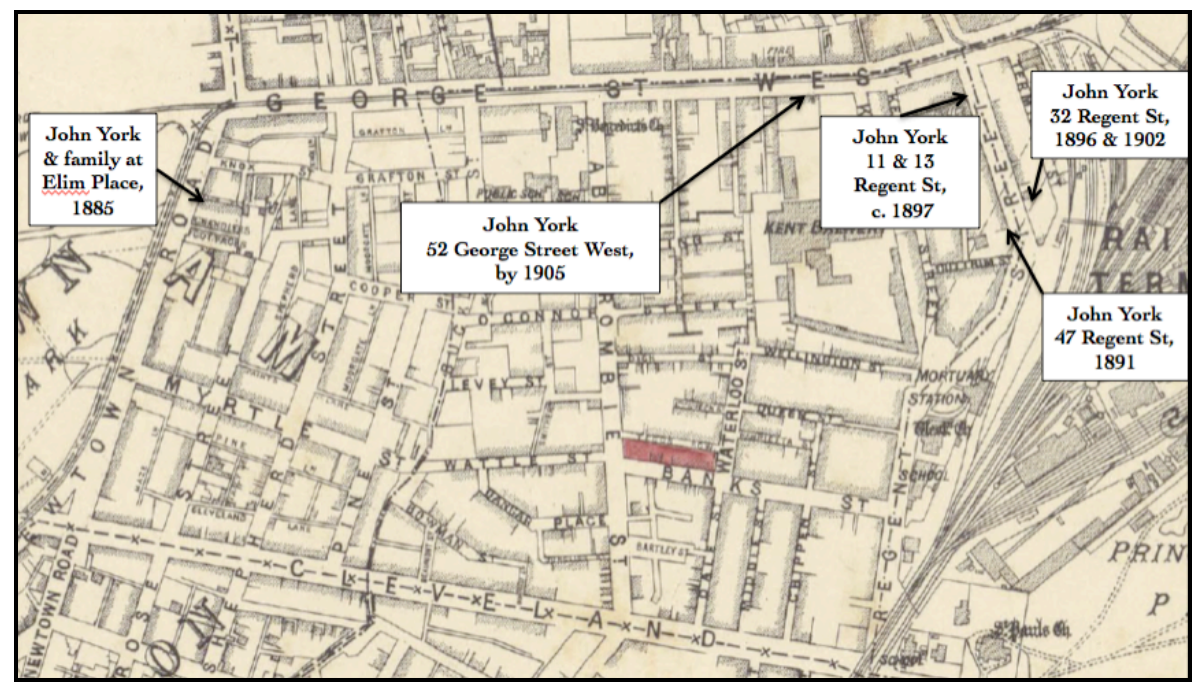

Figure 1 Map showing Chippendale in 1890s, with John York's homes and business locations indicated (the author)

\section{JOHN YORK JUNIOR AND SYDNEY'S BRASS BAND COMMUNITY}

During the decade following his arrival in Chippendale, John York junior appears to have forged a strong association with the brass band community around Sydney. Evidence of this can be found in October 1895 when a paragraph appeared in the Cumberland Argus and Fruitgrowers Advocate. It describes a rather touching community celebration in the honour of John York junior: 
An interesting presentation in connection with the Parramatta Model Band, took place on Saturday evening, when Mr. John York, junior, of Regent street, Sydney, was presented with an illuminated address from the band in recognition of the assistance he had at various times rendered. The address was a masterpiece from the brush of Mr. A. Tetley, of Granville. In one corner was a representation of the little bandstand in Alfred Square, and opposite was a lyre and at the top of the scroll were several bars of the music of "He's a Jolly Good Fellow." The address read as follows: - "To John York, junior, Sydney. Dear sir, we, the members of the Parramatta Model Band, recognising the many favors we have been the recipients of from you, our generous benefactor, have much pleasure in tendering our sincerest thanks for the great assistance you have from time to time placed at our disposal, with that unselfish and open hand and heart which denote the true philanthropist. It is our earnest desire that you may continue to be encompassed with health, happiness, and every success in business. Signed on behalf of the Parramatta Model Band, R Albury, hon. Sec., October 19, 1895." On leaving the train at Redfern the band struck up and played up to Mr York's door. Then the presentation was made by Bandmaster O'Shea and the recipient feelingly responded. The visitors were then escorted to $\mathrm{Mr}$. York's band-room where they spent a merry evening. The presentation was arranged on the quiet, and Mr. York was completely taken by surprise. ${ }^{21}$

This display of gratitude from the members of the Parramatta Band highlights the strength of the relationships that John York had managed to forge amongst the band community during his first decade in business. He had consciously pursued a marketing strategy of attracting potential customers from amongst the band community and this display of gratitude would seem to indicate that he had been very successful. Everyone acknowledged his commercial interests, yet this was a man to be trusted, even to repair one's beloved cornet. There is further evidence of what was to become a longstanding association with the NSW band community. York's sponsorship of a significant prize of the '20-Guineas Trophy' at the Grand Intercolonial Band Contest at the Exhibition Building in November 1896 can be found in the Sydney Morning Herald (see Figure 2). The sponsorship of prizes was a popular marketing 
strategy amongst makers and retailers. ${ }^{22}$ This advertisement illustrates that it was also one of the many advertising techniques that John York found necessary to utilize in order to advance his business amongst some fierce competition.

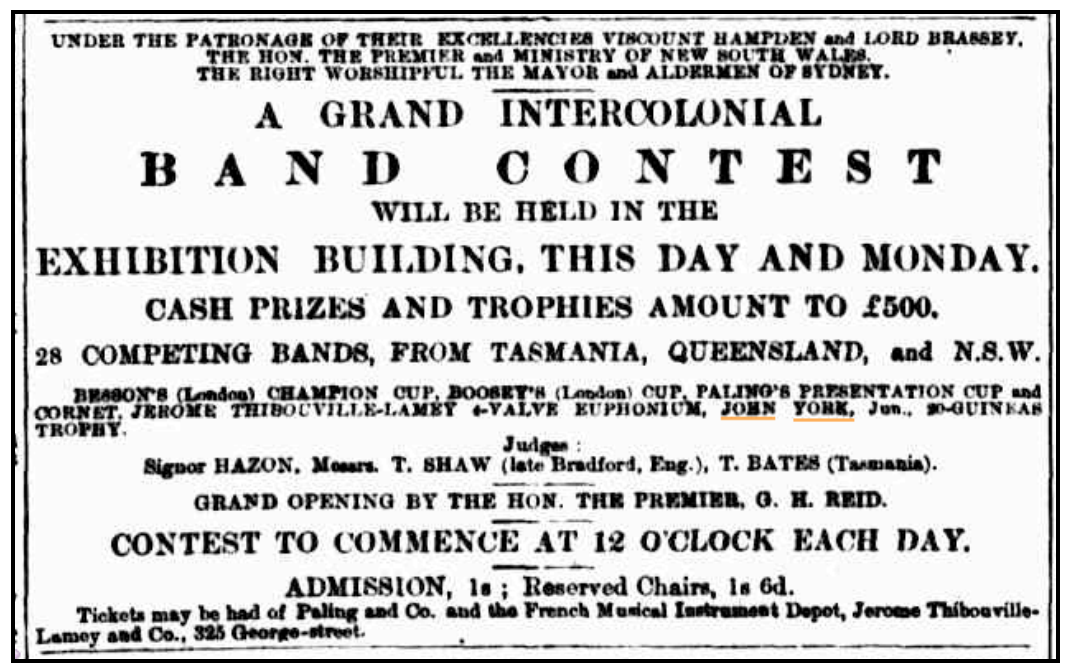

Figure 2 Advertisement for Band Contest in 1896; John York junior is a prize donor (Sydney Morning Herald, 7 November 1896)

\section{SYDNEY MUSIC INSTRUMENT RETAILING: JOHN YORK SENIOR AND HIS COMPETITORS}

In order to determine other methods John York used to successfully promote his locally made instruments and his repair business it is necessary to examine the commercial practices of the other makers and retailers who were offering brass instruments for sale in Sydney at the same time.

Three of York's principal competitors - Besson, Boosey and Palings were the other prize donors listed in the 1896 Band Contest advertisement. Due to a lack of surviving documentation, it is difficult to determine the impact that instrument price and quality, advertising, and the distribution networks of these individual makers and retailers may have had on York's business. For example, if we wish to conduct a simple comparison of various cornet prices from 1906-7 in order to determine if York's local instruments were of a similar price to those imported by W. H. Paling from Boosey in London, there are virtually no surviving Australian catalogues or pricelists for musical instruments from the early twentieth century with which to do this. Fortuitously we do have York's prices for the years 1906-7. ${ }^{23}$ But for information regarding the other retailers, it is necessary to utilise sources such as newspaper articles and advertising. 


\section{PRICE COMPARISONS}

In 1904, five new brass cornets were stolen from Palings in Sydney. They were imported, possibly from Boosey, and therefore had traceable serial numbers on each instrument. The cornets were officially valued at $£ 40$, so the price of each instrument would be approximately $£ 8$. By comparison, the most expensive cornet offered by John York - 'Extra Strong Silver Plated, Richly Engraved' - is listed at $£ 810$ s and therefore slightly more expensive than those found at Palings. It is also possible to trace the gradually decreasing prices of Palings' cheapest 'student model' cornets between 1901-1906. ${ }^{24}$ Starting from 55 shillings in 1901, by 1906 Palings could offer these cornets for 30 shillings. In 1906, York offered his cheapest model at a price of $£ 216$ (about 56 shillings). It therefore appears that the considerably lower prices of the imported instruments offered by York's competitors would have had the potential to make a significant impact on his ability to sell his low cost, 'student' model, which often represented a large volume of sales for a retailer.

\section{COMPETITION FROM BRITISH IMPORTS}

The imported instruments sold by Palings and Nicholsons, and their many outlets in other regional cities and states, came from two major European makers. Gustave Auguste Besson began manufacturing brass instruments in Paris in the 1830s, later opening a factory in London and virtually dominating the global trade in brass instruments by the turn of the century. It has been estimated that in the 1890s, the Besson factory was producing around 5000 instruments a year. ${ }^{25}$ The other major manufacturer, Boosey and Co - later Boosey and Hawkes - produced a more modest 1800 instruments a year. ${ }^{26}$ This British domination of the market and the resultant flood of cheaper imported instruments made business somewhat more difficult for individual makers such as York and even Higham in Manchester.

\section{MARKETING AND ADVERTISING}

The marketing resources employed by the large British manufacturers were daunting. Across Britain, nationwide contests and exhibitions attracted thousands of participants and appreciative audiences and the large manufacturers and retailers exploited these marketing opportunities mercilessly. They wined and dined committees and sponsors of brass bands. Madame Besson was observed as being particularly skilled in the technique of providing sponsored 'hospitality' and reportedly had nearly ten thousand brass bands on her 'books' with 


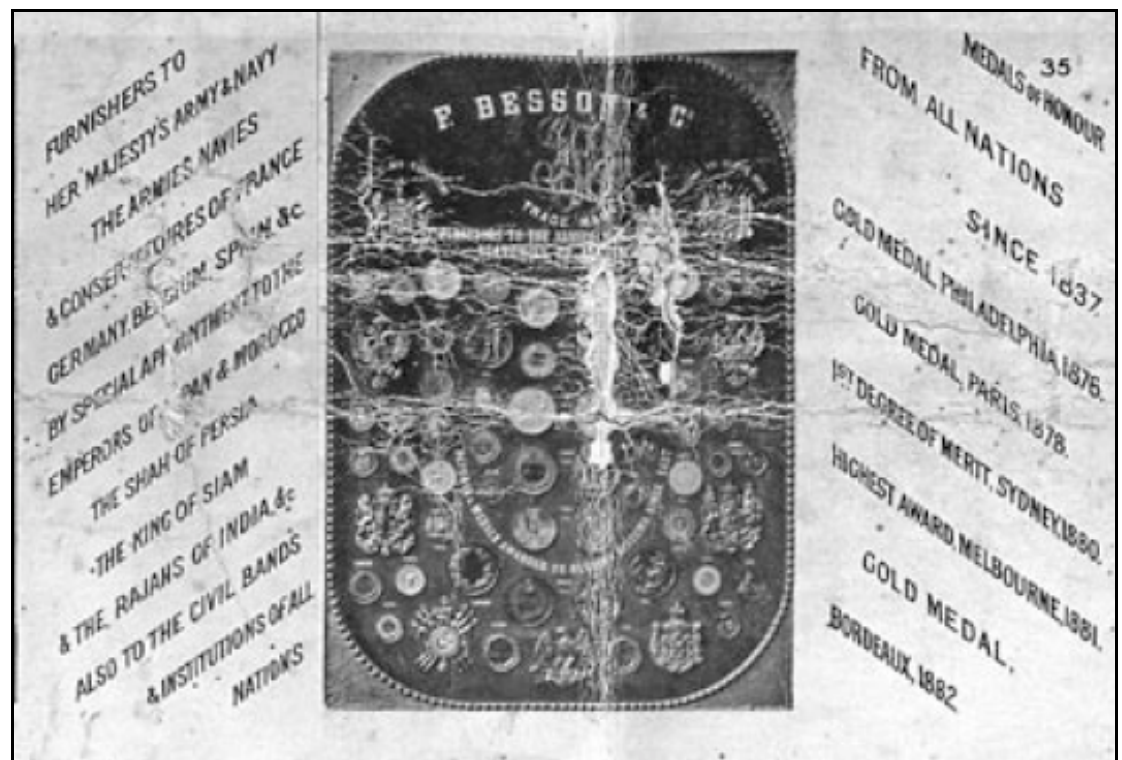

Figure 3 Section of a Besson advertising poster, c1885 (first prize in Sydney in 1880) ${ }^{27}$

whom she frequently communicated. ${ }^{28}$ Australia represented a mere one per cent of the brass musical instrument market for companies such as Besson and Boosey, ${ }^{29}$ yet it was viewed as a comparatively affluent market with a potential for growth and increased profit margins due to its isolation.

\section{PALINGS AND NICHOLSONS IN SYDNEY}

The growth of Australian music retailers such as Palings and Nicholsons, provided an extensive distribution network for the retailing and marketing of the imported instruments. Their numerous outlets in capital cities and regional centres ensured the British instruments found their way into the many remote areas of Australia. In Sydney, Palings and Nicholsons dominated the northern end of George Street. Their multi-storied emporiums carried a vast array of instruments, sheet music and later gramophone records and machines.

Nestled amongst other large emporiums along this fashionable end of George Street, they successfully catered to the expanding middle-class demand for 'respectable' entertainment, the most popular of which was music making in the home. Sales of pianos, violins, clarinets and sheet music dramatically increased, as did the demand for music teachers, composers, publishers and repairers. Crates of instruments from Besson and Boosey were landed at Darling Harbour, polished and displayed enticingly in handsome glass cases. 'In-house' repairers could complete a full circle of customer service. 


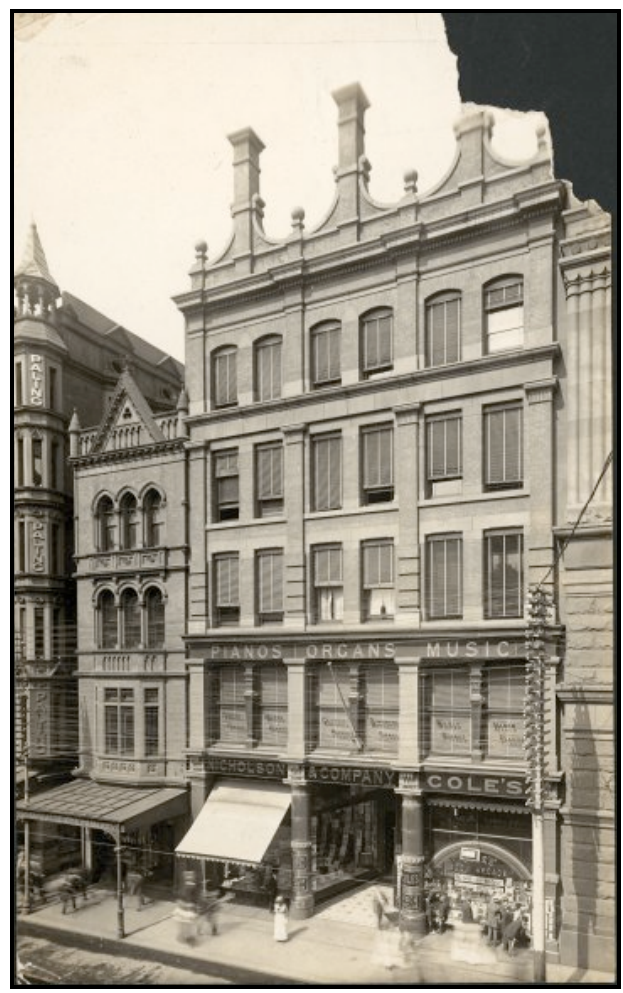

Figure 4 Nicholson and Co at 342 George Street, Sydney, c 1905. Palings emporium can be seen on the far left. (National Library of Australia, vn4776831)

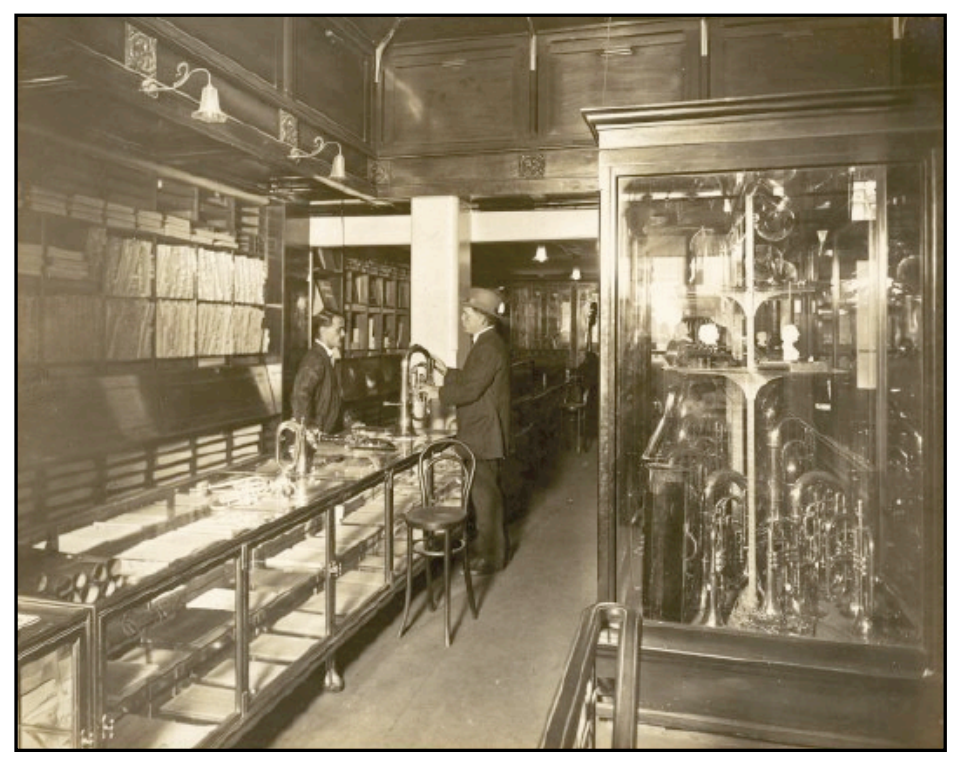

Figure 5 The Brass instrument display area in Nicholson \& Co, George Street, Sydney, c1905 (National Library of Australia, vn4776888) 
Like John York, these retail giants also wooed the growing brass band community and chased lucrative government contracts. A large number of periodicals specifically aimed at brass band members flourished from the 1890s with over a dozen in print all over the country by $1900 .^{30}$ These carried news, gossip, technical tips and most importantly advertisements and endorsements to thousands of readers. The self-published magazines distributed by Palings and Allans had considerable influence over the purchasing behavior of their readers.

\section{BANKRUPTCY AND FINANCIAL RECOVERY}

John York junior was declared bankrupt in late $1897 .{ }^{31}$ Whether this was due to the influx of cheaper imported instruments that were aggressively marketed by his competitors during the 1890s economic depression, poor financial management or a combination of circumstances beyond York's control, is now impossible to determine. It does appear, however, that York's personal life had started to sour in 1896 when quarrels with his neighbours in Sheffield Street, Auburn, resulted in him being charged and fined in the Parramatta Police Court. The report of the court case informs us that York was 'only home twice a week' and that 'Family matters never concerned him'. ${ }^{32}$ From available reports of his bankruptcy proceedings, he was also living and working at 11 and 13 Regent Street in Chippendale. It also seems that when York had attempted to expand his business and perhaps ensure his wife and children enjoyed a healthier environment in the suburbs away from the industrial grime of Chippendale, his financial situation had started to deteriorate further. The Auburn house and furniture were auctioned in February 1897 and the family then moved back to the house and shop in Chippendale, perhaps still trying to avoid bankruptcy.

In the years following his bankruptcy, York continued to trade from rented premises in Regent Street, Chippendale. An illustrated advertisement from Sands Directory of 1898 gives no hint of York's dire financial circumstances in the previous twelve months. The slogans and copy indicate a business that was diverse and confidently capable of accommodating every customer. The business later moved to a shop and house at 52 George Street West (now Broadway) sometime between 1902 and 1905. Tucked amongst a row of shops between Kensington and Balfour Streets and backing on to the prominent Tooth's Brewery, this shop fronted the main road out to Parramatta and was well placed to serve York's customers. The shop was easily reached via a choice of convenient public transportation: the trams that then ran along George Street, the Redfern and Central railway stations and Darling Harbor. 


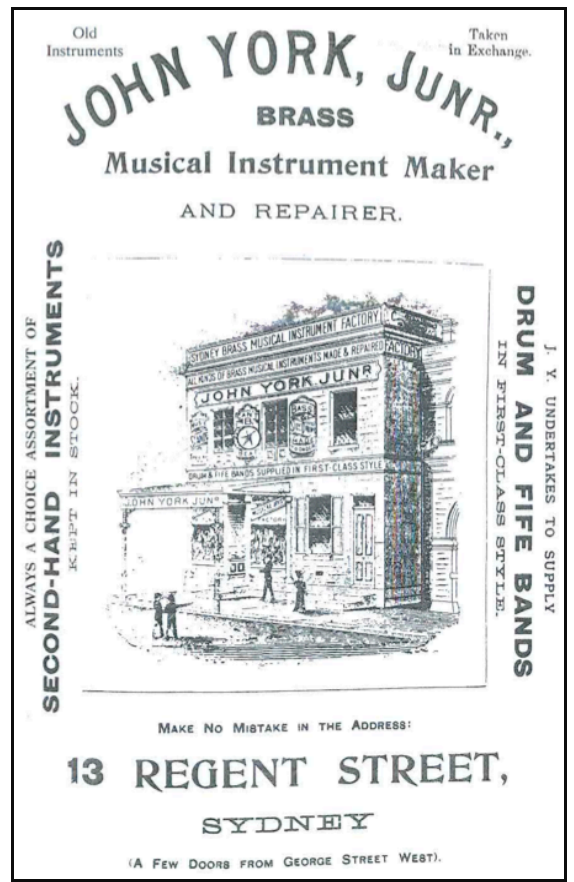

Figure 6 John York's as illustrated in Sands Directory, 1898

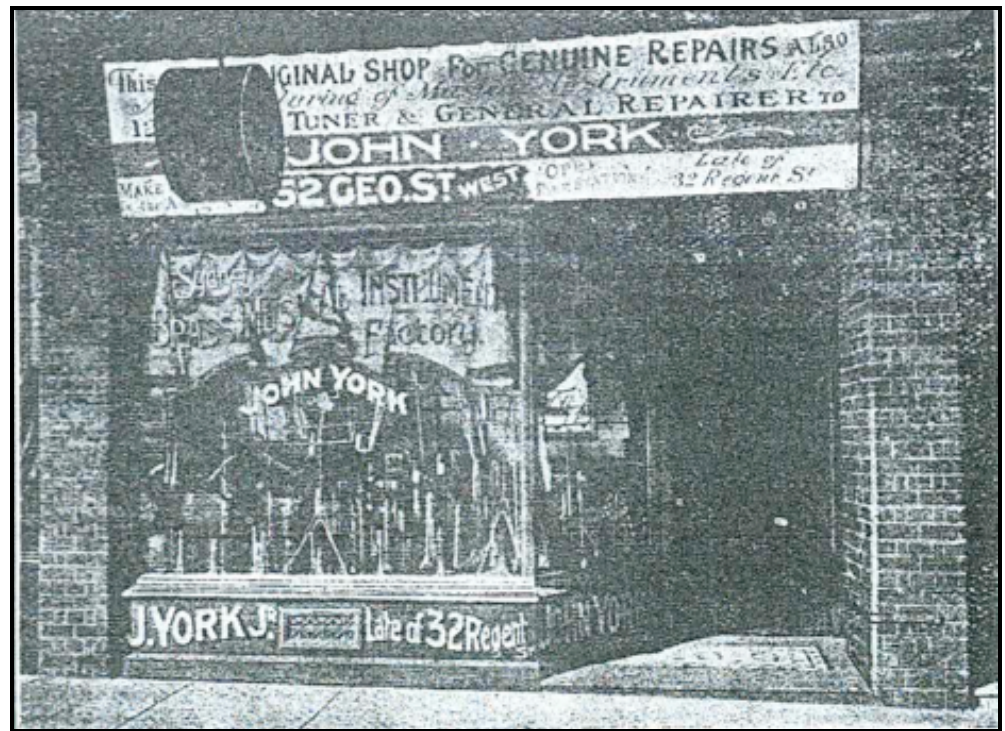

Figure 7 York's shop at 52 George Street West, Chippendale c1906

By 1911 the shop had expanded next door to number 54 - a likely indication that the business was performing well, although no documentation survives to support this. ${ }^{33}$ It would be reasonable to 
conclude then that York's business did not appear to have been solely reliant on the necessity of a large volume of sales of cheaper instruments. Other strategies seem to have been devised in order to continue the business. As previously noted, York appears to have relied heavily on both the customer relationships he had spent years cultivating and his personal involvement with band communities around Sydney. Additionally, his customers, both of amateur and professional, appreciated the solid technical skills York had learnt during his apprenticeship at the Higham factory in Manchester. This practical expertise was crucial to ensure the highest standards of manufacture and repair of brass instruments, and York made sure his customers were aware of it in his advertising:

Repairs are confined to a special department, fitted with special machines and mechanical devices with a specialist, the Proprietor himself, personally superintending. Advantages possessed by no other Firm in Australia, and recognized by the thousands whose repairs are constantly received from all parts of the Commonwealth. ${ }^{34}$

York's years as an apprentice at Higham seem not only to have impressed on him the importance of technical skills, but also the importance of marketing. As we will discover, many of the advertising techniques of his first employer can now be identified in York's only surviving catalogue.

\section{JOHN YORK JUNIOR'S CATALOGUE AND PRICELIST, 1906-1907}

Around 1904, a booklet entitled Peeps into the Famous Higham Band Instrument Factory was published..$^{35}$ The booklet illustrates and describes the processes of brass musical instrument manufacture in the Manchester factory where John York junior had served his apprenticeship between approximately 1873-1880. It appears that this publication did not go unnoticed by York. As an apprentice at Higham, John York would have observed the emphasis on the post-production side of the business - the shop displays and advertisements, the care taken over orders and repairs and the treatment of the brass band members who patronised the shop. When the Higham booklet reached him in Sydney sometime around 1905, York seems to have been sufficiently impressed with this early form of 'advertorial'.

In 1906, John York distributed a catalogue that is now a rare and significant historical document. York guides the reader through his modest Chippendale premises. Fortunately for contemporary historians 
it is detailed enough to provide rare and tantalizing glimpses into early twentieth century, small-scale manufacturing. The many valuable interior shots encapsulate the highly technical manufacturing processes that were occurring behind the unassuming frontage. The photographs of York's front showroom reveal a cramped and crowded shop. The variety of brass instruments and drums displayed in the cases is wideranging and comprehensive. There is an extensive range of cornets, tenor horns, euphoniums, slide and valve trombones and basses available for purchase. It is unknown whether York's were selling any imported instruments at this time. It is possible that some imported components may have been used in the manufacturing process, although this is also unconfirmed. Photographs of the other rooms that make up the factory reveal that all stages of manufacture appear to have taken place at York's premises. They illustrate the complex manufacturing process required to complete a brass musical instrument - hundreds of tools and patterns line the walls, alongside large quantities of raw brass components and instruments at various levels of finishing.

\section{JoHn YoRK's Final YeARS IN CHIPPENDALE}

York's catalogue of 1906-7 conveys the impression of a business full of promise. The factory appears well equipped with modern machinery and tools. The large variety of brass instruments ready to be finished and sold indicates a high level of commercial activity. His quality of instruments, repairs and personalised, instrument customisation were reputedly the best available in Sydney at the time. John York himself said that: 'The public judges a manufacturer more by the quality of his products than by anything else. ${ }^{36}$

York and his business prospered during the final decade of his life. He continued to sponsor contests and reinforced his association with the brass band community by serving on the NSW Band Committee. ${ }^{37}$ In 1902, he put himself forward as a councillor for Phillip Ward in the Sydney Local Government elections but was defeated by the two incumbent candidates. ${ }^{38}$ As a long-standing resident of Chippendale and a respected local businessman, he obviously had felt that he could represent his community.

John York's eldest son, John Thomas, known as Tom, had worked with his father since his arrival in Sydney with his parents at the age of six. Like his father, Tom worked, married, had a family and died in Chippendale. ${ }^{39}$ His younger brother William - Bill - who was born in Chippendale in 1889, also worked in the brass instrument factory. 


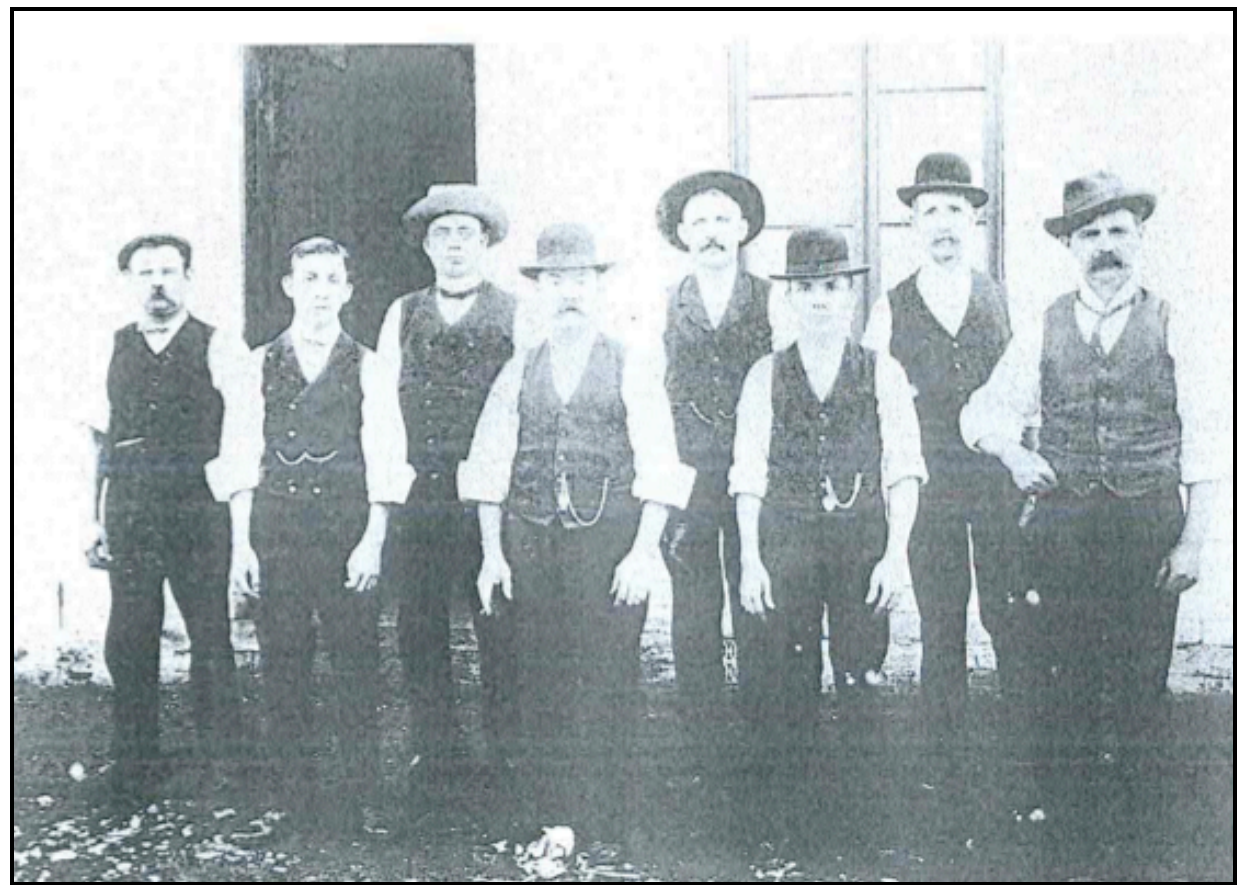

Figure 8 John York (fourth from the left) with sons, Tom (third from the right) and Bill (second from the left), c1905-6

Early in 1909, John York developed chronic nephritis, a chronic kidney infection that eventually led to his death in January 1910. He was 51 years old. His son, Tom, also succumbed to the same disease eight years later, aged only thirty-nine. Their deaths at relatively young ages, from the same complaint, are worth scrutinising. Chronic nephritis is now known to be caused by long-term exposure to 'chemical irritants' resulting in irreparable kidney damage..$^{40}$ Many of the chemicals that were used at the York factory are now classed as agents linked to such kidney damage. This toxic list includes lead used in solders and tube bending, arsenic used in some electrolytic processes and smelting and cadmium used in electroplating. ${ }^{41}$ It is also likely that the fumes emitted by other equipment in the foundry - such as the blast furnace and possibly the gas engine that was used to power the tools - contributed to an unhealthy atmosphere within the enclosed spaces in which they worked. This was a period before protective clothing and masks. Years of burnishing and polishing the raw brass to produce a perfect shine would have seen the Yorks and their workers inhaling significant amounts of minute, hazardous particulates.

Evidence of the respect and depth of feeling for John York within the brass band and Chippendale communities was captured in a photograph 
of his funeral procession along Regent Street on 6 January 1910. Following his death in 1910, his wife Elizabeth and son Tom (d1917) continued to run the business at 52 George Street West. During the next two decades, the York family witnessed considerable physical and social change in Chippendale and Sydney. Behind the Yorks' shop, Tooth's Brewery continued to grow, gradually purchasing many of the neighbouring premises along George Street to accommodate future expansion. Tooths are noted in the Council's Assessment Books as being the Yorks' landlord from at least $1911 .^{42}$ This section of George Street West had become congested with not only trams and a few remaining horse drawn vehicles, but also with an increasing number of motorcars, buses and lorries. ${ }^{43}$ The Council drew up plans to widen the road from Railway Square to City Road, requiring compulsory acquisition. St Benedict's Church, located just down the hill from York's premises, managed to hold up the process, which was not completed until the early 1940s.

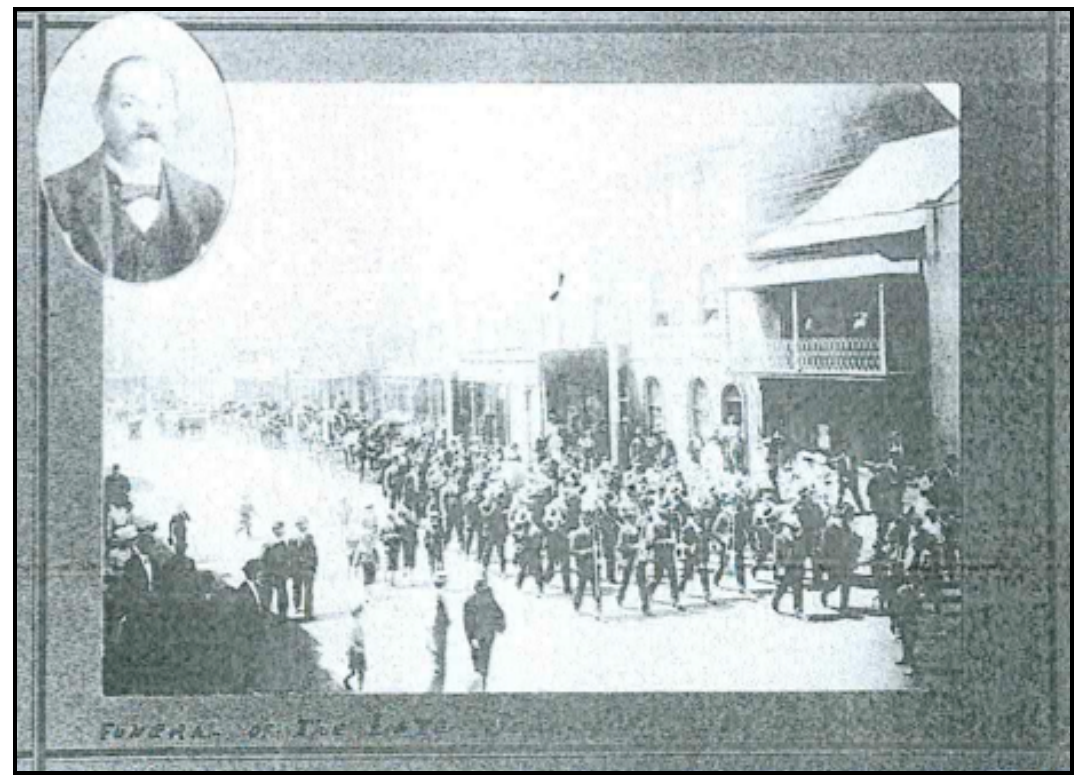

Figure 9 A Brass band leading the funeral procession for John York, 6 January 1910

Elizabeth York and her youngest son Bill moved to the eastern suburbs after 1936 and continued to serve the brass playing community of Sydney. ${ }^{44}$ Even today, there are brass players in the Sydney Symphony Orchestra who recall their teachers or brass band colleagues telling them to take their instruments to 'Yorkie's' for an expert repair or service. ${ }^{45}$ Elizabeth York died in 1945 at the age of 85. Bill, the last surviving son of John York junior, died in 1955 aged 76. 


\section{THE HUNT FOR A YORK INSTRUMENT CONTINUES}

Instruments manufactured by York's Sydney factory have yet to be located. There are a few likely reasons for the scarcity of these instruments. After 1964, a 'revolution' occurred regarding the standard pitch to which brass band instruments were to be tuned. Brass bands and Salvation Army bands played at a pitch significantly higher than orchestras, dance bands and pianos. ${ }^{46}$ The subsequent standardization of pitch meant that nearly all of the older instruments required conversion or became obsolete. As time passed, it became apparent that it was more practical to replace the entire instrument stocks of brass bands with new models, rather than persist with the unreliable intonation of deteriorating older instruments. Brass band instruments had become much cheaper and so the era of the 'disposable' instrument began. This practice continues today. With cheap imports from Asia, it is now often a more financially sensible option to throw away a damaged instrument than have it repaired.

Another reason for the disappearance of York's instruments is the gradual dissolution of hundreds of brass bands in Australia. At the turn of the century, nearly every country town or municipal council had its own band. The decline began in the 1960s when many rural communities started to shrink and the younger residents moved to the city for better opportunities and education. In the cities, the demand for community music making also declined. Entertainment could be found at home and musical tastes drastically changed. Interestingly, some regional areas are re-discovering the positive educational and social aspects that a good brass band can offer both children and adults. ${ }^{47}$ Hopefully it will be in such places that a York instrument may be discovered - a dusty case found in a shed or amongst grandparents' belongings being carted to landfill. Or is it too late to retrieve such valuable artefacts, which would remind us of our shared history of Sydney's small manufacturers and shopkeepers?

\section{ACKNOWLEDGEMENTS}

I am indebted to John York's descendant, Kel York of Wattle Glen, Victoria, who generously provided the material on a man and business who has been virtually invisible in the usual historical sources. Kel laboriously compiled his family history in the late 1990s, interviewing aged relatives who have since passed away. Without his efforts, it is likely that the history of John York's brass musical instrument factory in Chippendale would remain only known within his family.

Andrew Evans is Lecturer at the Sydney Conservatorium of Music 


\section{ENDNOTES}

${ }^{1}$ Sydney musicologist Graeme Skinner is progressively compiling an impressive biographical register of early colonial Australian musicians. A few entries mention some other possible manufacturers.

http: / / graemeskinner.id.au / australharmony.html <accessed September 2013>.

2 Sydney Morning Herald (SMH), 11 January 1884. Most of the family history used in this article has been taken from Kel York, A York Family History: Can't B Beat, selfpublished, Wattle Glen, 1999.

3 Sydney Morning Herald (SMH), 11 January 1884.

${ }^{4}$ Edward (b1856), Elijah (b1858), John junior (b1859) and Thomas (b1863).

${ }^{5}$ Mining companies operating in the area during this time such as Grimethorpe Colliery and Black Dyke Mills, founded and sponsored world famous brass bands. These bands continue to perform to international acclaim today.

${ }^{6}$ Trevor Herbert, 'Nineteenth-Century Bands: Making a Movement' in Trevor Herbert (ed), The British Brass Band: a musical and social history, Oxford University Press, London, 2000, pp10-67.

${ }^{7}$ E.D. Mackerness, A Social History of Music, Routledge, London, 1964, p164. Trevor Herbert also quotes contemporary sources in 'Nineteenth-Century Bands: Making a Movement', in Trevor Herbert (ed), The British Brass Band: a musical and social history, Oxford University Press, London, 2000, pp10-67.

${ }^{8}$ The Tanunda Town Band, reputedly the 'oldest band in Southern Hemisphere', was started in 1857 by the German Draeger brothers and continues to perform. From http: / / tanundatownband.com < accessed August 2012>. The Latrobe Federal Band in Tasmania began in 1872 and proudly calls itself the 'oldest continuing functioning brass band in Australia': https: / / sites.google.com/site/latrobefederalbandinc/Home/history <accessed September 2013>

${ }^{9}$ Arnold Myers and Niles Eldredge, 'The Brasswind Production of Marthe Besson's London Factory', The Galpin Society Journal, vol lix, 2006, pp43-75.

${ }^{10}$ The document 'Peeps into the Famous Higham Band Instrument Factory' was originally published in the London Military Mail, 19 August 1904. This copy was provided by Gary Newborough, and is found on http: / / manchesterhistory.net/ manchester / goneforever.html <accessed September 2013>

${ }^{11}$ ibid.

${ }^{12}$ Clifford Bevan, 'Higham, Joseph,' in Stanley Sadie (ed), The New Grove Dictionary of Musical Instruments, Macmillan, London, 1984.

${ }^{13}$ This technical expertise was to be passed on to his sons, who were still highly regarded amongst the Sydney brass fraternity until the business closed in the mid twentieth century.

${ }^{14}$ The three children who accompanied them were John Thomas (b1879), Emily (b1880) and Elizabeth (b1884).

${ }^{15}$ Shirley Fitzgerald, Chippendale: beneath the factory wall, Halstead Press, Ultimo, 2007, p32.

${ }^{16}$ Some of the cottages in Elim Place were built in the 1830s and had originally provided accommodation for workers at Robert Cooper's distillery, located next door and fronting onto the road to Parramatta. See Fitzgerald, ibid, p17.

${ }^{17}$ John York (senior) and Tom (1863-1913) soon left to work in Melbourne not long after 1897. John senior died in 1898.

${ }^{18}$ James Henry (b1887), William (b1889) and May (b1894).

${ }^{19}$ City Assessment Books 1891, online database, http: / / ww3.photosau.com/CosRates/scripts/home.asp <accessed August 2012>.

${ }^{20}$ The Yorks moved to nos 37, 32, 13 and back to 32 Regent Street.

${ }^{21}$ Cumberland Argus and Fruitgrowers Advocate, 26 October 1895. 
${ }^{22}$ Algernon Rose, Talks with Bandsmen: A Popular Handbook for Brass Instrumentalists, original edition, London, 1895. Facsimile edition, Tony Bingham, London, 1995, p 202.

${ }^{23}$ A Facsimile of John York's catalogue and price list, 1906-7, still survives in the possession of the York family.

${ }^{24}$ Freemans Journal, 28 December 1901; The Carcoar Chronicle , 27 May1904; The Brisbane Courier, 8 December 1906.

${ }^{25}$ Arnold Myers and Niles Eldredge, 'The Brasswind Production of Marthe Besson's London Factory', The Galpin Society Journal, volume lix, 2006, pp43-75.

${ }^{26}$ ibid, p48.

${ }^{27} \mathrm{ibid}, \mathrm{p} 61$. Original poster held by North Winds instrument repairers, Perth, Scotland.

${ }^{28}$ Chas. E. Timms, 'It started in 1837: the Story of a Famous Brass Wind Instrument Maker', in Frank Wright (ed), Brass Today, London, Besson \& Co., 1957. See also Rose, op cit.

${ }^{29}$ Myers and Eldredge, 'The Brasswind Production', p48.

${ }^{30}$ These titles included Intercolonial Bandsman, Intercolonial Brass and Military Band Journal and Australian Band News.

${ }^{31} \mathrm{SMH}, 28$ September 1897

${ }^{32}$ Cumberland Argus and Fruitgrowers Advocate, 31 October 1896; 16 January 1897.

${ }^{33}$ City of Sydney Archives, City Assessment Books 1911, online database, http:/ / www3.photosau.com/CosRates/scripts/home.asp <accessed August 2012>.

${ }^{34}$ Facsimile of John York catalogue and pricelist, 1906-7, p20.

${ }^{35} \mathrm{http}$ / / / manchesterhistory.net/ manchester / goneforever.html <accessed September 2013>.

${ }^{36}$ York catalogue and pricelist, 1906-7, introduction.

${ }^{37}$ SMH, 29 October 1900.

${ }^{38} \mathrm{SMH}, 19$ November 1902.

${ }^{39} 28$ Goold Street, Chippendale in 1907 and 80 Eveleigh Street, Redfern, 1917.

${ }^{40} \mathrm{http}$ : / / www.wikihealthy.com/diseases-of-the-urinary-system/chronicnephritis.html <accessed January 2012>.

${ }^{41}$ http: / / www.haz-map.com/ renal.htm <accessed January 2012>.

${ }^{42}$ City Assessment Books 1891, online database, http:/ / ww3.photosau.com/CosRates/scripts/home.asp <accessed August 2012>.

${ }^{43}$ Fitzgerald, Chippendale, p103.

${ }^{44}$ Exact date of closure of Chippendale premises and the address and closure date of later business in the eastern suburbs have yet to be determined.

${ }^{45}$ Personal communication, Paul Goodchild, Associate Principal trumpet, Sydney Symphony, May 2012.

${ }^{46}$ Trevor Herbert, 'Selling Brass Instruments: The commercial imaging of brass instruments (1830-1930) and its cultural messages', Music in Art, vol 29, 2004, p213.

${ }^{47}$ The recent revival and success of the Gunnedah Band in regional NSW would seem to confirm this. 